\title{
EDITORIAL: A THANK YOU FROM THE CONFERENCE CHAIRMAN
}

In 2013, several staff members from the SUERC radiocarbon dating laboratory attended the 7th Radiocarbon \& Archaeology Symposium in Ghent. It was a highly successful and interesting meeting and confirmed to us that we should bid for the next one. Everyone at the meeting seemed positive when we made our presentation and so we set about organising the 8th Symposium. What became very apparent was how technology had moved on since Marian Scott, Doug Harkness and I organised the 15th International Radiocarbon Conference in Glasgow (August 1994). Software packages now allowed us to deal with registration, abstract submission, payments, etc. that in 1994 had to be done in a much more tedious fashion. I am indebted to one of our staff, Brian Tripney, who undertook the role of Conference Secretary and dealt with all of that. I am also grateful to all our other staff and student members of the laboratory who took on the many and varied tasks, both prior to the conference and during the actual week, and carried them out so well: Philip Naysmith, Derek Hamilton, Elaine Dunbar, Kerry Sayle, Tony Krus, Piotr Jacobsson, Jessica Bownes, Helen Kinch, Kerrie-Anne Lang, Iain Murdoch, Linzi Straub and last but certainly not least, our honorary lab member, Marian Scott (Statistics, University of Glasgow), who has been a close collaborator for many years.

Thanks are also due to our scientific organising committee for their help in suggesting themes, and reviewing abstracts and manuscripts, etc.: Professor Alex Bayliss (Historic England/ University of Stirling, United Kingdom); Dr Nancy Beavan (New Zealand); Professor Clive Bonsall (University of Edinburgh, United Kingdom); Dr Ricardo Fernandes (Christian Albrechts Universität - Kiel, Germany); Professor Tom Higham (University of Oxford, United Kingdom); Rod McCullagh (formerly Historic Environment Scotland, United Kingdom); Dr Guy De Mulder (University of Ghent, Belgium); Professor Eddie Peltenburg (deceased) (University of Edinburgh, United Kingdom); Professor Johannes van der Plicht (University of Groningen, Netherlands); Dr Alison Sheridan (National Museums of Scotland, United Kingdom) and Professor Mark Van Strydonck (Royal Institute of Cultural Heritage, IRPA-KIK, Belgium).

The funding provided by the following organisations is greatly appreciated: Historic Environment Scotland for funds towards general conference organisation, reception and session sponsorship; Scottish Archaeological Research Framework (ScARF)/Society of Antiquaries of Scotland for the provision of student bursaries and session sponsorship; National Electrostatics Corporation, Ionplus, AOC Archaeology Group, Wessex Archaeology, Queen's University of Belfast Chrono Centre, GUARD Archaeology, Archaeological Research Services Ltd, SUERC and University of Glasgow for session sponsorship.

The Royal College of Surgeons of Edinburgh provided excellent facilities and their infrastructure made hosting the conference very straightforward for us. In addition, their food throughout the week and for the conference dinner was excellent.

Dr Rebecca Jones (Head of Archaeology and World Heritage for Historic Environment Scotland) provided an interesting and insightful opening address that we really appreciated.

Professor Mark Van Strydonck (Royal Institute for Cultural Heritage, Belgium) and Professor Alasdair Whittle (Cardiff University, United Kingdom) gave entertaining plenary talks on "A personal reflection on 40 years of radiocarbon and archaeology" and "Hunting history in the archaeology of Neolithic Europe”, respectively. 


\section{viii Editorial}

Thanks are also due to all our session chairs.

Our most popular social event was the "Whisky Tasting" given by Kirsteen Campbell from Edrington, one of Scotland's leading distillers. Kirsteen provided a very interesting insight into whisky production and blending and introduced many of our delegates to Scotch Whisky. A good night was definitely had by all who attended.

Thanks are due to Mark McClure, Kimberley Tanner Elliott and Tim Jull for all their help in the preparation of these proceedings for Radiocarbon.

Finally, I would like to express my thanks to all the conference participants for their interesting presentations, both poster and oral, and for their good company and humour.

We hope to see you in Georgia in 2019!

Gordon Cook

Conference Chairman 